\title{
KONTAKTO SU ŠUNIMIS PANAUDOJIMAS VYKSTANT SOCIALINES PAGALBOS PROCESUI
}

\section{EGLĖ PAPLAUSKAITÉ, JUSTINAS PLADAS, DONATA PETRUŽYTÉ \\ VILNIAUS UNIVERSITETAS}

Straipsnio tikslas - atskleisti šuns ir žmogaus ryšio panaudojimo socialinès pagalbos procesui galimybiu ivairovę. Tikslui pasiekti atlikta mokslinés literatūros analizè ir kokybinis tyrimas. Straipsnyje pateikiamas teorinis kontakto su šunimi panaudojimo pagrindimas, empiriniai šio pagalbos būdo poveikio ịrodymai, aptariamos šunu itraukimo i pagalbos procesa formos, reikalingas pasirengimas, apribojimai, trumpai apžvelgiama situacija Lietuvoje.

\section{IVADAS}

Socialiniai darbuotojai dažnai dirba su žmonėmis, kurie turi nedaug pozityvių gyvenimo patirčių, susiduria su sunkumais kurdami konstruktyvius santykius, stokoja pasitikèjimo savimi spręsdami įvairias problemas, yra mažai motyvuoti kreiptis socialinès pagalbos. Tad labai svarbu ieškoti alternatyviu, inovatyvių pagalbos priemonių, kurios padètų socialiniams darbuotojams efektyviau teikti paslaugas savo klientams. Viena iš tokių priemonių - gyvūnų įtraukimas ị socialinès pagalbos procesą.

Lietuvoje gyvūnų panaudojimas teikiant socialinę pagalbą - naujas, bet vis daugiau susidomèjimo sulaukiantis pagalbos metodas. Peržvelgus 
mokslinę ir publicistinę šios srities literatūra, galima daryti prielaidą, kad Lietuvoje dažniausiai taikoma žirgų terapija, o profesionalumu išsiskiria delfinų terapija. Deja, klientai, norintys pasinaudoti šia pagalba, dažnai susiduria su prieinamumo problemomis. Todèl šunys gali būti puiki alternatyva pačioms įvairiausioms klientų grupèms, kurioms bendravimas su gyvūnu labai reikalingas, - būtent dèl savo prieinamumo ir palyginti pigaus išlaikymo. Tačiau pasaulinejje praktikoje populiariausia šunų terapija Lietuvoje kol kas žengia pirmuosius žingsnius ir dar nèra isitvirtinusi.

Tiek gyvūnų terapijos apskritai, tiek šunų terapijos konkrečiai moksliniai tyrimai Lietuvoje yra tik pradedami ir itin negausūs. Išskirtini Kreivinienès delfinų terapijos tyrinejjimai (Kreivinienė, Rugevičius, 2009; Kreivinienė, Pertulla, 2012). Yra neseniai paskelbtų hipoterapijos tyrimų rezultatų (Anužienè, Večkienè, 2011; Rutkienė, Straubergaitė, Baranauskienè, Savenkovienè, 2012; Straubergaitè, Jocas, 2008; Berneckè, Muckus, Juodžbalienè, 2011). Taip pat yra aprašytos kontakto su naminiais gyvūnèliais terapinio taikymo galimybès (Šinkariova, Gudonis, Trakūnaitè, 2008 a ir b).

Nesant jokio akademinio kaniterapijos ${ }^{1}$ tyrimo Lietuvoje, mums atrodo tikslinga rinktis kokybinio, panoramiškai apimančio šunų panaudojimo pagalbos procesui galimybes tyrimo. Tokio pobūdžio tyrimas gali paskatinti socialinio darbo praktikus, mokslininkus ir specialistų rengime dalyvaujančius pedagogus apsvarstyti galimybes, kylančias iš žmogaus ir šuns ryšio svarbos mūsų kultūroje. Taigi buvo nutarta atlikti tyrimą ir detaliau išsiaiškinti, kokios yra kontakto su šunimi panaudojimo galimybės teikiant pagalbą. Tad šio straipsnio tikslas - atskleisti šuns ir žmogaus ryšio panaudojimo vykstant socialinès pagalbos procesui galimybes, analizuojant mokslinę literatūrą ir apžvelgiant Lietuvos ir užsienio ekspertų nuomones bei patirtis. Atliekant kokybini tyrimą, buvo apklausti 6 informantai: 2 specialistai iš JAV, 2 - iš Lietuvos

\footnotetext{
${ }^{1}$ Lietuvoje kol kas nèra aiškaus termino šiame straipsnyje aptariamam pagalbos būdui ìvardyti. Yra siūlomi du terminai: dogoterapija (anglu k. dog - šuo) ir kaniterapija (lotynų k. canis - šuo). Kaip teigiama Lietuvos kinologų draugijos tinklalapyje, „dèl termino ìtvirtinimo pradètos konsultacijos su Valstybine lietuvių kalbos komisija (Kaniterapijos pradžiamokslis).
} 
bei 2 socialiniai darbuotojai iš Lietuvos ${ }^{1}$. Duomenys analizuoti naudojantis grindžiamosios teorijos principais (Strauss, Corbin, 2008).

\section{KONTAKTO SU ŠUNIMIS PANAUDOJIMO VYKSTANT SOCIALINÉS PAGALBOS PROCESUI TEORINIS PAGRINDIMAS}

Ši pagalbos forma „vis dar stokoja vieningos, plačiai pripažintos, empiriškai pagrịstos teorinès sistemos, kuri paaiškintų, kaip ir kodèl žmogaus ir šuns kontaktas gali būti terapiškas" (Kruger, Serlpell, 2010, 37). Mokslinèje literatūroje užsimenama apie įvairius terapinius mechanizmus, grindžiamus remiantis skirtingomis teorinėmis perspektyvomis (biologinėmis, antropologinėmis, sociologinėmis, psichologinėmis). Apibendrinant galima teigti, kad skirtingos teorijos orientuojasi i i ivairias šunų savybes, kurios vienaip ar kitaip gali būti naudingos pagalbos proceso metu. Šio tyrimo kontekste aktualiausia būtų Rogerso humanistinè teorija.

${ }^{1} 2$ specialistai iš JAV:

- 1 informantas -Žmogaus - gyvūno ryšio tyrimų instituto direktorius, Denverio universiteto socialinio darbo magistro programos „Socialinis darbas, panaudojant kontaktą

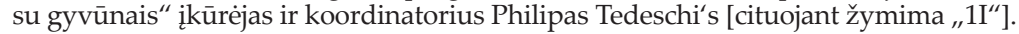

- 2 informantas - Kolorado valstijos programu, panaudojant kontaktą su gyvūnais, vykdomoji direktorè, šeimos psichoterapeutè Linda Chassman [cituojant žymima „2I“].

2 specialistai iš Lietuvos:

- 3 informantas - kontakto su šunimi panaudojimo socialinès pagalbos procesui pionierė Lietuvoje - Niūfaundlendų-lansyrų klubo pirmininkė Margarita Racinienè [cituojant žymima , $\left.3 \mathrm{I}^{\prime \prime}\right]$.

. 4 informantas - projekto „sunuterapija.lt“ iniciatorè Evelina Tamulaitienė [cituojant žymima ,"4I"].

2 socialiniai darbuotojai iš Lietuvos:

. 5 informantas - socialinis darbuotojas, besidomintis kontakto su šunimis panaudojimo galimybėmis dirbant su klientais, studijų metais savanoriškos veiklos metu neformaliai ir fragmentiškai naudojęs savo šuni (programa Big Brothers, Big sisters; Pal. J. Matulaičio parapijos Socialinis centras ir kt.) [cituojant žymima ",5I"].

. 6 informantas - socialinis darbuotojas, besidomintis kontakto su šunimis panaudojimo galimybėmis dirbant su klientais, Jaunimo savarankiško gyvenimo namuose neformaliai ir fragmentiškai naudojantis savo šuni [cituojant žymima "6I"].

Rengiant ši straipsnį buvo atsižvelgta į informantų pageidavimus dèl anonimiškumo laikymosi. Savanoriai pageidavo, kad jų tapatybė nebūtų atskleista. Ekspertai neprieštaravo, kad jų pavardès būtų minimos straipsnyje. Be to, šiuo atveju anonimiškumą užtikrinti būtų itin sunku dèl mažo šios srities ekspertų skaičiaus ir jų išskirtinumo. 
Rogerso teorijos „pamatas - nepriklausomo žmogaus koncepcija“ (Corsini, Wedding, 2011, 146). Kiekvienas žmogus turi vidinių išteklių ir motyvacijos augti ir aktualizuoti save, nepaisant jo psichikos sutrikimų ar aplinkos ribojimų. Norint padèti žmogui keistis, tobulèti, įveikti gyvenimo sunkumus, reikalingos trys sąlygos. Tai kongruentiškas pagalbos specialistas, rodantis klientui besąlygišką pagarbą ir empatišką supratimą (Corsini, Wedding, 2011).

1. Kongruentiškumas - tai pagalbos specialisto autentiškumas, tikrumas, nuoširdumas. Tai, ką specialistas išreiškia išoriškai, turi būti kongruentiška jo vidui, atitikti jo vidinę patirti. Kaip aiškina Rogersas (2005, 54), būti kongruentiškam „reiškia, kad visus savo jausmus ar nuostatas, kad ir kokie jie būtų, aš suvokiu. Tą akimirka, kai taip nutinka, aš būnu vieningas, ar integruotas asmuo, todèl galiu būti tas, kas iš tikrųjų esu." Kuo daugiau kongruentiškumo, tuo didesnè tikimybè, kad klientai pradès keistis ir augti.

Daugelis gyvūnu, ypač šunys, pasižymi greitomis ir nedviprasmiškomis reakcijomis i (ne)malonius stimulus, t. y. išreiškia tai, ką jaučia, tokiu būdu suteikdami klientui visada autentišką grižtamaji ryši (Kruger, Trachtenberg, Serpell, 2004). O tai yra vienas iš esminių kongruentiškumo aspektų.

2. Besąlygiška pagarba susijusi su neteisiančiu, laisvu nuo vertinimo pagalbos specialisto santykiu su klientu. Kuo daugiau pagalbos santykiuose tokio nusiteikimo, tuo didesnè tikimybė pokyčiui įvykti. Kaip teigia Rogersas (2005), beveik kiekvienoje mūsų gyvenimo sferoje esame veikiami išorinių i̇vertinimų bausmėmis ir paskatinimais. „Tai gerai“, „Tai niekam tikę", ,Tai verta aukščiausio pažymio“. „Matau, kad, kaip ir visi kiti, pernelyg dažnai taip vertinu. Tačiau patyriau, kad tokie vertinimai neskatina asmeninio augimo, todèl netikiu, kad jie yra sudedamoji pagalbos santykio dalis" (Rogers, 2005, 57).

Dažnai žmonėms yra pakankamai sunku pasiekti tokio besąlygiško žmogaus priėmimo, kokiu pasižymi šunys. Daugelio veislių šunys turi ypatingą gebejjimą rodyti besąlygišką ir neteisianti dėmesį, pagarbą netgi visai nepažǐstamiems žmonėms, tuo suteikdami ypatingą emocinę paramą (Kruger, Serpell, 2010).

3. Empatija - lemiamas veiksnys kliento progresui. Nors empatijos samprata apima plačiau (,Ar galiu pasinerti ì kito asmens jausmų ir asmeniniu prasmiu pasauli ir matyti ji jo akimis? Ar galiu ieiti i jo 
asmenini pasauli tiek, kad visai išnyktų noras ji vertinti arba teisti?" (Rogers, 2005, 56)), vienas svarbiausių jos aspektų yra gebejjimas tiksliai pajusti, fiksuoti, ką išgyvena kitas žmogus. Svarbu klausytis ne tik žodžių, reikia išgirsti už verbalinio ir neverbalinio komunikacijos turinio slypinčias prasmes.

Šunys labiau nei bet kurie kiti gyvūnai pasižymi itin dideliu jautrumu neverbaliai reiškiamoms žmogaus emocinėms būsenoms ${ }^{1}$. Teigiama, kad šunys yra empatiški, t. y. geba "pajusti“ žmogaus jausmus bei emocijas ir i juos atsiliepti (Kruger, Trachtenberg, Serpell, 2004).

Taigi matome, kad šunys pasižymi keletu savybių, kurios humanistinès teorijos rèmuose sudaro esmines prielaidas efektyviam pagalbos santykiui susikurti. Kaip toliau matysime, šunų dalyvavimas iš tiesų daugeliu aspektų palengvina, paspartina ir praturtina pagalbos procesą.

\section{KONTAKTO SU ŠUNIMIS PANAUDOJIMO VYKSTANT PAGALBOS PROCESUI EFEKTYVUMO EMPIRINIAI IRODYMAI}

Žmogaus - šuns ryšys yra apibrěžiamas kaip abipusiai naudingas ir dinamiškas žmogaus ir šuns santykis, apimantis elgsena, būtiną abiejų subjektu sveikatai ir gerovei (pagal AVMA). Anot Fine'o (2010), nors daugelis specialistų, i̇traukiančių šunis i pagalbos procesa, neabejoja tokios darbo formos veiksmingumu, mokslinių įrodymų kol kas stokojama. Trūksta sistemingų didesnio masto tyrimų, kurie galètų atskleisti mechanizma, kaip šunų ittraukimas ị pagalbos procesą sukelia teigiamus pokyčius, ir atsakyti i tokius klausimus kaip: kokioms sąlygoms esant šunu panaudojimas yra veiksmingiausias? Kokioms klientų grupėms labiausiai padeda? Kokias problemas padeda efektyviausiai išspręsti?

Vis dèlto pavieniai moksliniai tyrimai įrodo, kad kontaktas su šunimi iš tiesų turi teigiamą poveikị ịvairioms žmogaus gyvenimo dimensijoms. Ju rezultatai atskleidžia kontakto su šunimi teigiamą poveikị klientų psichikai (geresnè nuotaika, mažiau streso, baimės, sumažėjęs subjektyvus skausmo suvokimas, didesnis subjektyviai suvokiamas energingumas,

\footnotetext{
${ }^{1}$ Tyrimai rodo, kad šunys turi sudètingą kognityvinę sistemą ir jausmus bei aštrų sensorinį suvokimą. Biologijos antropologai atrado, kad šunys išskirtinai gerai atpažista žmogaus siunčiamus signalus ir žmogaus elgesị supranta geriau nei genetiškai žmonèms artimesni primatai, geba tiksliai suvokti net subtilius rankų gestus ir žvilgtelëjimus (Virányi, 2008; Soproni, 2001).
} 
gebejjimas geriau susikaupti ir atsiminti ir kt.), bendravimui ir tarpusavio santykiams (daugiau socialinių interakcijų, geresnè verbalinė ekspresija, sklandesnè socializacija), fiziologijai (susinormalizavęs kvėpavimo ritmas, širdies ritmas, kraujo spaudimas) (Yeh, 2013; Marcus, Bernstein, Constantin, Kunkel, Breuer, Hanlon, 2012; Tsai, Friedmann, Thomas, 2010; Coakley, Mahoney, 2009; Chu, Liu, Sun, Lin, 2009; Sobo, Eng, Kassity-Krich, 2006; Martin, Farnum, 2002; Walsh, Mertin, Verlander, Pollard, 1995; Fick, 1993; ir kt.). Taigi nors šie tyrimai ir fragmentiški, o ju rezultatai kai kuriais atvejais prieštaringi, tačiau jie sudaro prielaidas teigti, kad ši pagalbos forma gali būti naudinga bent jau tam tikriems klientams tam tikrais atvejais ir suteikia pagrindą toliau plètoti šią pagalbos formą ir jos tyrimus.

\section{IŠSKIRTINĖS ŠUNS SAVYBĖS NAUDINGOS SOCIALINÉS PAGALBOS PROCESUI}

Remiantis mokslinės literatūros ir atliktų interviu analize, galima teigti, kad šunys - gyvūnų rūšis, ypač tinkama teikiant profesionalią pagalbą ivairioms klientu grupèms.

Žmogaus ir šuns abipusis prisitaikymas. Anot informantų [1I, 2I, 5I], viena svarbiausiu šuns išskirtinuma iš kitu augintiniu rūšiu aiškinančiu perspektyvu, nuo kurios reikètu pradèti, yra tai, ka vadiname evoliuciniu tęstinumu. Tai koncepcija, kuri atskleidžia, kaip gyvūnas evoliucionuoja kartu su savo aplinka. Šunys apie 10-80 tūkstančių metų evoliucionavo būdami šalia žmonių. Ir mes, žmonès, evoliucionavome būdami šalia šunų ${ }^{1}$. Todèl kuo giliau tyrinėjamas žmogaus - šuns ryšys, tuo aiškiau, kad mūsu rūšys tampa vis labiau susijusios tarpusavyje [1I].

Šuns prisitaikymas prie žmogaus. Šunys yra žmonių elgesio ekspertai. Jie yra išskirtinai pajègūs santykiams su žmogumi, daugeliu atvejų jie tam turi daugiau gebejjimų nei žmonès. Anot 1I, vykstant evoliucijai

\footnotetext{
1 Šuo yra vienas iš nedaugelio gyvūnų, kuris pats pasirinko gyventi šalia žmogaus - dar priešistoriniais laikais kai kurie vilkai pastebejjo, kad jiems naudingiau gyventi šalia žmonių gyvenviečių, jie jautėsi saugūs, kad visada turès maisto, o žmonèms ši prijaukintų vilkų kompanija taip pat buvo naudinga, nes saugojo nuo įvairių plèšrūnų. Iš šių prijaukintų vilkų atsirado naujas simbiotinis porūšis - canis lupus familiaris - ir po daugybès, kai kuriais atvejais net tūkstančių metų selekcijos dabar turime ịvairias šunų veisles, pritaikytas įvairiausioms žmogaus reikmėms.
} 
žmonès, megzdami tarpusavio santykius, apsileido komunikacijos kokybès prasme. Mes klausomés tik vieni kitu žodžiu, bet ignoruojame beveik visa kita informacija apie vienas kita. (...) kaip mes kvepiame, kaip mes girdimés, kaip atrodome, mes beveik laikome tai intuityvumu, bet šunys išgyveno šiuo būdu, jie bendrauja vieni su kitais šiuo būdu ir bendrauja su mumis šiuo būdu [1I]. Taigi jie yra labai gerai prisitaikę suprasti žmones ir dèl to jie dabar yra protingiausia gyvūnų rūšis gyvūno - žmogaus ryšio kokybės požiūriu. Šuo stebi žmogų beveik visą laiką. Pasak 1I, jie beveik nepraleidžia nė menkiausios smulkmenos, net milimetrinio antakio judesio ar lūpos timptelejjimo, balso tono ar nežymaus povyzos pasikeitimo. Jie žino, ka ketinate daryti, dar iki jums suvokiant, kq darysite [1I].

Žmogaus prisitaikymas prie šuns. Kita vertus, žmonès tiek susigyveno su šunimis, kad dabar gali atpažinti kuo ivvairiausius jų elgesio, laikysenos bruožus. Pavyzdžiui, žmonès, kurie negali matyti šuns, bet girdi jo lojima, gali pasakyti, kokio tipo lojimas [1I]. Evoliucionuojant lojimas išsivystė kaip funkcija, skirta ne tiek šunims bendrauti tarpusavyje, kiek šunims bendrauti su žmonèmis. Mes esame stipriai prisirišę prie šunų ir tiek juos pažistame, kad santykis su jais leidžia mums jaustis geriau, saugiau, patogiau tarp kitų žmonių.

Šuns fiziologija. 1I teigia, kad, kaip rūšis, šunys yra gerai prisitaikę palaikyti ryši su žmonemis ir patirti naudą iš to. Fizinis kontaktas šuns smegenyse sukelia oksitocino išsiskyrimą. Šunims tai patinka - jie jaučiasi saugiau, geriau, panašiai kaip vaikai, kai juos apkabini. Tą pati patvirtina ir 3I. Šuns organizme vyksta labai aktyvūs fiziologiniai procesai, dèl to jiems tiesiog būtinas bendravimas su žmogumi, nes jie turi atiduoti savo energija [3I]. Taigi šunys turi visas savybes, kokių galètume norèti teikdami pagalbą kontaktu su gyvūnu: gyvūnai, kurie mėgsta būti tarp žmonių, kurie patys gauna naudą iš bendravimo su žmonėmis, - būtent tokie gyvūnai labiausiai tinka pagalbai, nes jie nebūna negatyviai susijaudinę, nepatiria kančios atlikdami šị darbą.

Šuns charakterio tinkamumas. Pasak 6I, neatsitiktinai šunų įtraukimas i profesionalios socialinès pagalbos procesą yra taip paplitęs JAV, Kanadoje, Australijoje. Juos iš kitų gyvūnų išskirti prasminga dèl charakterio ypatybių. Jų teikiamą emocinę paramą tiesiogiai atskleidžiar 4I asmeninè patirtįs: augdama pastebejjau, kad šunys duoda daug meilés, švelnumo [4I]. O 1I teigia, kad šuo yra gyvūnas, kurio elgesys ir temperamentas leidžia jam būti nuspejjamam ir patikimam dirbant su pačiomis ìvairiausiomis klientu 
grupèmis [1I]. Pabrěžtina, kad netgi skirtingus naminius gyvūnus savo darbui naudojantys naminiu gyvūnu terapijos specialistai, šuni laiko terapinio gyvūno modeliu (pvz., terapijai naudojama katè pasirenkama dèl jos charakterio „šunišku“" savybiu) [6I].

Prieinamumas. Šunys yra tapę iprasta mūsų kasdienio buitinio ir socialinio gyvenimo dalimi. Dèl to jų panaudojimas teikiant profesionalią socialinę pagalbą įvairiuose instituciniuose kontekstuose ir įvairiausioms klientų grupėms pasižymi santykiniu efektyvumu. Kadangi šunys yra gana maži ir mobilūs gyvūnai, darbas su jais nereikalauja tokių didelių erdvių ir finansinių resursų kaip delfinų ar žirgų terapija. Drąsiai galima pritarti 1I minčiai: jeigu galime gauti tuos pačius teigiamus efektus dirbdami terapini darba su tinkamu šunimi, kodèl mums reikètu naudoti egzotinius gyvūnus?

\section{KONTAKTO SU ŠUNIMI PANAUDOJIMO SOCIALINĖS PAGALBOS PROCESE FORMOS IR METODAI}

Mokslinejje literatūroje daugiausia dèmesio skiriama kontakto su šunimi naudojimui psichoterapijos ir kitose medicinos srityse. Vis dèlto galima rasti tekstų, kuriuose aptariamos ir šios pagalbos formos galimybès dirbant socialini darbą. Anot 1I ir 6I, tai yra igalinimu grịsta prieiga, kuri gali būti taikoma įvairioms klientų grupėms įvairiausiuose organizaciniuose kontekstuose. Būtent socialiniai darbuotojai gali integruoti žmogaus - gyvūno ryši i i socialinès paramos sistemas (Tedeschi, Fitchett, Molidor, 2006). Pasitelkdami šunis, jie gali pasirūpinti igalinančios atmosferos kūrimu ir specifinių socialinių programų, skirtų klientų gyvenimo kokybei gerinti, vystymu (pvz., tokiose institucijose kaip psichiatrinės ligoninės, vaikų, neigaliųjų ar pagyvenusių žmonių globos istaigos ir pan.). Būdai, kuriais galima panaudoti šuni socialinės pagalbos procesui, yra labai i̇vairūs, pasižymintys skirtingu formalizacijos lygmeniu, reikalaujantys skirtingo pasiruošimo. Galima išskirti dvi pagrindines formas, kurios labiausiai ištyrinėtos ir aprašytos mokslinèje literatūroje: (1) intervencija panaudojant ryši su specialiai parengtu šunimi, (2) kliento šuns įtraukimas i pagalbos procesą.

Intervencija panaudojant ryši su specialiai parengtu šunimi. Ittraukti šunis i profesionalios socialinès pagalbos organizavimą galima siekiant îvairių tikslų. Visu pirma, galima šiuos gyvūnus panaudoti kaip 
instrumentus emocinio klimato reguliavimui. Reikia tiesiog leisti šunims būti tose patalpose, kur lankosi klientai ir yra teikiamos paslaugos. Tai gali padaryti pagalbos procesą patrauklesni, labiau atpalaiduojanti, motyvuojanti (Fine, 2010). 1I teigia, kad šunys gali būti panaudojami ūminių krizių poveikiui amortizuoti: ištikus tokioms krizèms kaip kad Bostono sprogdinimai ar žmoniu šaudymai, pirmas dalykas, kurio žmonés prašo, yra terapiniai šunys [1I]. Specialiai parengtas šuo taip pat padeda palaikyti emocinį komfortą pakliuvus į ilgalaikes stresą ir nemalonius išgyvenimus keliančias situacijas: aš buvau ligoninèje, onkologinëje ligoninejje Jeruzalèje, kur vykdoma terapijos panaudojant kontakta su gyvūnu programa pačios ligoninès patalpose. Vaikai, prijungti prie dializès aparatu, kai reikia išsédèti nuo triju iki keturiu valandu, gali turèti šalia ju ant lovos sédinti gyvūna [1I]. Antra, didesnis šuns įtraukimas ì socialinès pagalbos procesą padeda greičiau sukurti pasitikejjimo ryši tarp kliento ir socialinio darbuotojo, igalina lengviau ịveikti kultūrinius, socialinès, lyties, amžiaus, gyvenimiškos patirties skirtumų keliamus barjerus ir atsiverti. Anot 6I, vien pats naminiu gyvūnu buvimas pagalbos proceso metu stimuliuoja bendravima ir mažina stresa aptariant skaudžias temas su klientais, kurie patiria socialine atskirti, izoliacija ir yra praradę socialinius igūdžius, būtinus integravimuisi i visuomene, grupiu. Socialiniams darbuotojams pravartu žinoti, kad šuns dalyvavimas pagalbos procese gali padèti ir kitiems pagalbos specialistams užmegzti su klientais santykius ir igyti tarpusavio pasitikejjimą. 1I pamini įdomu pavyzdį: mes turime šuni, kuris dirba mūsu nusikaltimu prieš vaikus skyriuje, Policijos departamente čia, Denveryje. <...> Užuot nusikaltimo vietoje pasirode su savo ginklais ir neperšaunamomis liemenemis, kurie vaikams atrodo grésmingi, jie pasirodo su savo ginklais ir neperšaunamomis liemenemis, bet ir su labai gražiu, draugišku šunimi. O tai kokybiškai skirtinga patirtis vaikams.

Trečia, kliento ir šuns tarpusavio sąveika gali pateikti informacijos apie klientą. Specialistas gali stebėti, kaip skirtingi klientai bendrauja su šunimi, kokias emocijas kontaktas su gyvūnu provokuoja, kaip pats šuo reaguoja į kliento verbalinę ir neverbalinę komunikaciją. Socialinis darbuotojas gali panaudoti šią informaciją kaip stimulą darbui su kliento problemomis (Fine, 2010).

Ketvirta, šuns lietimas, glostymas - didelè pagalba praktikuojančiam socialiniam darbuotojui. Dèl egzistuojančių profesinės etikos apribojimų tokio tipo emocinès paramos jis pats negali suteikti klientui. İdomu tai, kad pagalbos specialistų naudojamas šuo yra jų asmeniškai treniruotas, 
jie kartu sudaro komandą. Šuniui tenka ne tiek pasyvaus įrankio, kiek aktyvaus dalyvio ir pagalbininko vaidmuo. 2I teigia: Rupertas <asmeninis informantès terapinis šuo > yra labai žaismingas ir priimantis žmones gyvūnas, todèl aš ji naudoju dirbdama su žmonèmis, kuriems reikia ka nors glostyti.

Galiausiai, aktyvesnis šuns įtraukimas i pagalbos procesą (žaidimas, dresiravimas, komandu davimas ir kt.) gali padèti įsisąmoninti iracionalius įsitikinimus, keisti mąstymo modelius, lavinti ịgūdžius, mokytis naujų elgesio būdų ir kt. (Fine, 2010). 1I pateikia pavyzdị: îkalinimo isstaigoje esantiems žmonèms atvežami šunys iš gyvūnų prieglaudos. Kaliniai užsiima jų dresiravimu. Tai daugialypę naudą teikianti veikla. Viena vertus, tai beglobių gyvūnų reabilitacija. Kita vertus, kaliniams šis procesas padeda pajusti asmeninę galią prisidèti prie reikšmingo pokyčio (t. y. nesocializuotų gyvūnų socializacijos). Taip išauga jų pasitikejjimas savimi ir kitais, didejja motyvacija pažinti save ir harmonizuoti savo santykius su aplinka. Galiausiai, dalyvavimas socialiai naudingoje veikloje gali padèti jiems integruotis į visuomenę.

Žaidimas su šunimi taip pat gali būti tinkama pagalbos forma toms klientų grupèms, kurios pasižymi motyvacijos stoka, kurioms îprasti pagalbos būdai kelia nuobodulị, atmetimo jausmus ir pan. 4I pateikia toki pavyzdį: jie ir dresiravo, ir žaide < ..> paaugliams tai iš tiesu îdomu. Žaidimo su šunimi integravimas i pagalbos procesą neretai padeda klientams įveikti stresą bei lengviau atsiverti. Be to, žaidimas su šunimi gali padèti lavinti specifinius socialinius igūdžius. Liepdami vykdyti komandas ir triukus klientai gali ugdytis gebejjima komunikuoti pasitikinčiu, tvirtu balsu, gebejjima aiškiai išreikšti, ko nori [2I].

1I ir 2I ypatingą dèmesi skiria vienam iš naujausių metodų - kongruencijai. Tai dar tik besiformuojantis, kaip moksliškai pagrịstas, metodas, kurị naudoja JAV profesionalai. Kongruencija reiškia dviejų dalykų atitikimą vienas kitam, beveik jų suvienodinimą. Kai pagalba teikiama įtraukiant i terapiją šunis, pasiekiamas sinchroniškumas, jaučiamas būnant labai arti gyvūno. Šiuo atveju svarbu didelio besiilsinčio šuns širdies plakimo dažnis, kuris apie 10 vnt. lètesnis nei žmogaus. Terapiniai šunys yra išmokomi nugara glaudžiai prisiglausti prie vaiko, gulima ant grindu (taip saugiau šuniui). Prieš tai biogrižtamojo ryšio aparatu vaikui parodome jo širdies dažni ir kvépavimo ritma, kad jis žinotu, kq jo kūnas turi išmokti, kaip jam kontroliuoti savo kūna [1I]. 2I taip pat dalijasi patirtimi: aš dirbu su klientais, turinčiais nerimo sutrikimu; vienas iš dalyku, kuriuos pritaikome užsiëmimu metu, yra prisiglaudimas prie šuns gulint ir méginimas pajausti jo širdies ritma ar ịsiklausyti i jo 
kvèpavima ir priderinti savo kvépavima prie šuns. Žmonès, gulèdami šalia šuns, visiškai atsipalaiduoja. Jie pajunta ramybès ir atsipalaidavimo kupiną fizinę ir emocinę būseną. Šis metodas ypač tinka potrauminei reabilitacijai. Ji naudojant galima padèti klientams pasiekti daugelio pozityvių pokyčių be vaistų, be hospitalizavimo, be invazinių procedūrų. Edukaciniai užsièmimai su šunimis - tai pažintinio pobūdžio veikla. Anot 3I ir 4I, į ši pagalbos būdą integruojamas paskaitų skaitymas, dalijimasis profesine ir/ar asmenine patirtimi, i̇vairios vaizdinès medžiagos demonstravimas ir „bendravimas“ su šunimis. Panašu, kad kol kas tai dominuojantis metodas siekiant platesnio kontakto su šunimi panaudojimo socialines pagalbos procesui Lietuvoje [6I]. 4I pateikia toki pavyzdi: mus pasikvietè vaiku reabilitacijos centras. Pravedeme toki seminara. Kineziterapeuté papasakojo apie šunu terapijos praktika užsienyje, parodè skaidriu, o aš su savo šuniukais, su savo vaiku, kurie jau daug metu patiriame šunu terapijos nauda, buvome praktinis pavyzdys. Anot 6I, kadangi ši veikla sulaukia didelio įvairių klientų grupių susidomejjimo ir pasisekimo, tai yra geras pagrindas šią pagalbos formą profesionalizuoti.

Kliento šuns ịtraukimas ị pagalbos procesą. Informantai šio pagalbos, panaudojant kontaktą su šunimi, būdo neakcentuoja. Tačiau dèl temos dėstymo nuoseklumo mes pristatysime ši aspektą remdamiesi kitų autorių atliktais tyrimais.

Kliento šuo kaip diagnostinè priemonè. Pagal Risley-Curtisso, Holley ir Wolfo (2006) žmogaus ir naminių gyvūnų ryšio tyrima, 97 proc. augintinių savininkų, kurių dauguma turèjo šunį, laiko savo gyvūną šeimos nariu. Taigi naminiai gyvūnai tampa šeimos sistemos dinamikos dalimi. Kadangi šunys yra jautrūs šeimos emocinei atmosferai, jie atspindi šeimos sistemos funkcionavima, ịtampą ir krizines situacijas. Tai gali būti potencialiai svarbu socialiniams darbuotojams ir vaikų teisių apsaugos specialistams. Vizituojant namus, tiriant šeimos problematika, atliekant atvejų vertinimus klientų namuose šuo gali tapti esamos situacijos indikatoriumi. Pavyzdžiui, toks socialus ir prisitaikęs prie žmogaus gyvūnas kaip šuo gali būti puikus „lakmuso popierèlis“ vertinant padèti šeimoje: bijantis garsu, staigių judesių šuo yra patikimas simptomas, kad šeimoje smurtaujama.

Kitas pavyzdys - žiaurus elgesys su gyvūnais kaip signalas, jog šeimos dinamika disfunkcinè. Vis daugiau tyrimų patvirtina koreliaciją tarp smurto prieš augintinius ir kitų smurto šeimoje formų (Ascione, 2005; Walton-Moss, Manganello, 2005). 
Pagal Merz-Perezo ir Heide (2004) tyrima, žiaurus elgesys su augintiniu taip pat gali būti indikatorius fakto, kad smurtaujantysis pats gali būti smurto auka. Pavyzdžiui, vaikai, kurie buvo fiziškai ar seksualiai išnaudoti, dažniau smurtauja prieš augintinius nei nuo išnaudojimo nenukentėję vaikai (De Viney, Dickert ir Lockwood, 1983).

Arkow (2007) teigia, kad klientus svarbu matyti jų aplinkos kontekste, stebėti pastoviai vykstančių abipusių interakcijų su reikšmingais artimaisiais procesą. Turint omenyje, kad augintiniai yra daugelio klientų šeimos sistemos dalis, klausimų apie augintinius įtraukimas į vertinimo apklausas yra labai pagristas.

Kliento šuo kaip savipagalbos ir paramos priemonè. Atsiradus šeimos sistemos dinamikai šuo gali tapti socialinès pagalbos šaltiniu ir padidinti šeimos narių psichologini atsparumą probleminėms situacijoms. Planuojant intervenciją svarbu atsižvelgti i̇ kliento socialinị tinkla, ir būtų tiesiog neracionalu neatsižvelgti i šuni kaip i psichologinio atsparumo šaltini, jeigu klientas ji laiko savo šeimos dalimi. Kai kuriais atvejais, ypač suaugus ir išsikrausčius vaikams, mirus sutuoktiniui, vyresnio amžiaus žmonèms vienatvę padeda išgyventi jų augintinis. Anot 6I, ị toki žmogu negalima žiūrèti kaip i absoliučiai vieniša, nes jis bent iš dalies patenkina savo bendravimo, fizinio kontakto poreikị. Pozityvūs santykiai su šunimis gali būti laikomi apsauginiu faktoriumi vaikams ir suaugusiesiems namuose, kuriuose smurtaujama. Ryšys su jais turi reabilitacijos po traumuojančios patirties potenciala, kuris gali būti panaudotas socialiniams darbuotojams atejus ị pagalbą. Kūrybiškas socialinis darbuotojas gali atrasti veiksmingų būdų, kaip panaudoti kliento ryši su šunimi, ir igalinti ji tvarkytis su daugeliu problemų. 1I ir 2I teigimu, ne tik su vienatve, stresu, bet ir su tokiomis sudètingomis problemomis kaip nerimo sutrikimai, agorafobija ir pan.

\section{PASIRENGIMAS}

Dèl specialistų pasirengimo, verta paminèti, kad šio pagalbos būdo profesionalumo lygmuo gali labai ịvairuoti. Ji gali taikyti tiek pagalbos profesijų diplomus turintys asmenys, tiek savarankiškai pasirengę savanoriai. Tiek vieni, tiek kiti gali netgi naudoti panašius metodus (pvz., žaidimas su šunimi, šuns glostymas ar pan.), tačiau būtent nuo specialisto kompetencijos priklauso poveikio "gilumas". 
Kalbant apie specifinį pasirengimą reikia paminèti, kad žmonės, taikantys ši pagalbos būda, dažniausiai būna išklausę specialius kursus. Anot 1I ir 5I, tik Amerikoje, Denverio universitete, yra įsteigta antrosios pakopos studijų programa „Socialinis darbas panaudojant kontaktą su gyvūnais“, pagal kurią vienas kursas yra skiriamas pagalbos panaudojant kontaktą su šunimis specifikai.

Anot 5I, žmogui, norinčiam užsiimti tokio pobūdžio veikla, reikalingos kelių sričių žinios:

- žinios apie gyvūnų (ypač šunų) psichologija

- žinios apie konkrečią klientų grupę, su kuria ruošiamasi dirbti,

- žinios apie bendravimo psichologija, konsultavima, darbo grupejje metodiką.

Kitas svarbus šios temos aspektas yra šuns parengimas, kuris susideda iš kelių etapų. Visų pirma būtina apmąstyti, kam bus teikiama pagalba, koki metodą planuojama taikyti, ir tinkamai parinkti šuns veislę. Išanalizavus 3I, 4I, 5I ir 6I interviu, galima teigti, kad daugelis šunu veisliu yra tinkamos pagalbai. Paukštinès (retriveriai) ir darbinės (pvz., aviganiai) veislès pasižymi aktyvumu, todèl ypač tinkamos žaidimo su šunimi metodui. Kovinès veislès (pvz., pitsbuliai) labai jaučia žmogu, tačiau yra netinkami savimi nepasitikintiems, depresyviems žmonėms, nes kontaktas su jais reikalauja tvirtumo. Niūfaundlendai labai nejudrūs, todèl gali būti ypač tinkami tokiam metodui kaip šuns buvimas ir naudojami darbui su sergančiais, neigaliais, pagyvenusiais žmonėmis. 4I dalijasi savo asmenine patirtimi: j̧sigijau du auksaspalvius retriverius. Šia veisle daug domejjausi, skaičiau, kad jie - visiški vaiku draugai, visiškai neturi jokiu, sakykim, urzgimo, kandžiojimo ipročiu, iš viso neturi jokios agresijos. O 3I pasakoja: mūsu veislès yra niūfaundlendai ir landsyrai, jie, pagal savo charakterio savybes, labai tinka panašiems užsiemimams, kadangi be galo ramūs, mégsta vaikus, mégsta žmones, bendrauti ir yra visiškai neagresyvūs. Anot 6I, pagalbai beveik visai netinkamos šunų veislès: bastetai (dèl melancholiškumo ir nepaklusnumo), kurtai ir balthaundai (dèl netinkamumo dresiravimui).

Parinkus tinkamą šunį reikia ji parengti ir dresiruoti. Tam tikrais atvejais dresiravimas gali tapti pagalbos proceso dalimi. Tačiau dažniausiai šuo yra parengiamas iprastų dresuotojų. Anot 5I, šalyse, kur šunu terapija yra labiau išplitusi, egzistuoja ir dresuotojai, besispecializuojantys rengti terapinius šunis. Tam tikri nauji pagalbos metodai su šunimis (pvz., kongruencija) 
reikalauja ilgalaikio profesionalaus šuns paruošimo ir nuolatiniu jo treniruočių komandoje su pagalbos profesijos profesionalu. Reikia ir už gyvūnų gerovę atsakingo specialisto supervizijų. Pasak 1I, tinkamai parinktas ir dresuotas šuo yra toks, kurio elgesys ir temperamentas leidžia jam būti nuspejjamam ir patikimam darbe. 2I atkreipia dèmesi, kad ypač svarbu ir specialisto profesionalumas, nes tik turint specialiu žiniu galima tikslingai prognozuoti norima efekta [2I].

\section{APRIBOJIMAI}

Išanalizavus mokslinę literatūrą bei informantų atsakymus, matyti, jog pagalbos specialistui, į savo darbą įtraukiančiam kliento ir šuns kontakta, gali kilti tam tikrų sunkumų.

Anot 5I ir 6I, visų pirma yra klientų, kurie nemėgsta šunų arba jų bijo. Dirbant su tokiais žmonėmis kontaktas su šunimi gali būti naudojamas tik profesionalios psichoterapijos kontekste (pavyzdžiui, siekiant padèti klientui išsivaduoti iš tokio pobūdžio baimès).

Pasak 5I, kita netinkama klientu grupè - žmonès, alergiški šunims. Jiems būtu galima taikyti šią pagalbos formą tik labai atsargiai parenkant šuns veislę (pavyzdžiui, pudelius, kurie mažiau alergizuoja nei kitos šunų veislès).

Taikant šią pagalbos formą susiduriama su didesne sužeidimų rizika. Todèl specialistas turi prisiimti dvigubą atsakomybę, t. y. užtikrinti ne tik kliento, bet ir terapinio šuns saugumą (Chandlers, 2005).

Be to, specialistas turi būti pasirengęs papildomoms išlaidoms (šuns insigijimas, jo parengimas, priežiūra, išlaikymas, transportavimas ir kt.).

\section{SITUACIJA LIETUVOJE}

Pasak lietuvių informantų, Lietuvoje pradejo rastis įvairios iniciatyvos ir organizacijos. Jos dar nepasižymi aukštu profesionalumu ir labiau orientuojasi į veiklą su šunimis negu i šunų terapiją. 4I pasakoja: mes važiuojam pas vaikučius [ị reabilitacijos centrus ir pan.], kuriu šunys išvis prieš tai nemate ir jie juos sutinka, džiaugiasi kartu su téveliais. 4I, remdamasi savo patirtimi, prieina išvada, kad Lietuvoje yra poreikis, šiuo pagalbos būdu domisi net tie žmonès, kurie iki tol neturejjo kontakto su šunimi 
patirties. Žmonès iš praktikos ir asmenines patirties intuityviai suvokia tai, kas igyja vis didesni pripažinima mokslinejje bendruomeneje ir pasaulyje [4I]. 5I pateikia kiek kitokią nuomonę, t. y. atkreipia dèmesi i tai, kad Lietuvoje dar vyrauja mentalitetas, jog šuns vieta būdoj. Ir tai apriboja šio pagalbos būdo taikymo plètrą. $6 \mathrm{I}$ taip pat teigia, kad Lietuvos socialinès pagalbos institucijose kol kas skeptiškai žiūrima į šunų panaudojimą teikiant pagalbą. Informantas pateikia pavyzdi, kad garbaus amžiaus sulaukusiems žmonèms skirtos socialinès globos istaigos Lietuvoje dažniausiai nureikšmina ši santykį. Užuot pasinaudoję augintinio teikiama nauda, priverčia klienta atsisakyti jo, o tai yra labai traumuojanti patirtis abiem [6I]. Informantas toliau plètoja minti, kad panašiai vyksta ir moterų, atsiskyrusių nuo partneriu smurtautoju, globos įstaigose: priimama su vaikais, bet tik ne su augintiniais, nes jie nevertinami kaip svarbus paramos šaltinis [6I]. Pasak 5I, vienintelè sritis, kurioje bandoma įtraukti i pagalbos procesą šunis, - tai darbas su sergančiais vaikais ịvairiose ligoninèse, sanatorijose ir pensionatuose. Bet tai susiję ne tiek su šių institucijų vidine veikla, kiek su tarpinstituciniu bendradarbiavimu. Pasak 5I, Lietuvoje greičiausiai taip pat egzistuoja ivairios privačios praktikos, nes keliskart vyko mokymai, ị kuriuos atvažiuoja iš Lenkijos. Ir gali būti apie dvi dešimtis žmoniu, dalyvavusiu juose. Jie bando taikyti, bet nesistemingai [5I].

\section{IŠVADOS}

Šuo - evoliucijos procese labai gerai prisitaikęs padèti žmogui gyvūnas: turi išskirtinių gebejimų bendradarbiauti su žmogumi, savo ilgalaikio vystymosi šalia žmogaus dèka geba net tobuliau už žmones suprasti jų kūno kalbą ir siunčiamus signalus. Tinkamai socializuotas šuo - patikimas, prognozuojamas kompanjonas ir emocinès paramos šaltinis. Kadangi šunims patinka dirbti su žmonèmis, įtraukiant šią gyvūnų rūši i socialinès pagalbos procesą neiškyla etikos dilemų.

Humanistinès teorijos požiūriu, šuns dalyvavimas vykstant socialinès pagalbos procesui sudaro esmines prielaidas pagalbos santykiui kurtis (padidina kongruentiškuma, besąlygišką prièmimą ir empatiją). Be to, yra tyrimų, i̇rodančiu šuns įtraukimo ì pagalbos procesą poveiki fizinei, psichinei ir socialinei žmogaus gyvenimo dimensijai.

Kontaktas su šunimis teikiant socialinę pagalbą gali būti naudojamas dviem būdais: intervencija panaudojant ryši su specialiai parengtu šunimi 
(tai buvimas su šunimi, jo lietimas, žaidimas su juo, dresavimas ir kt.) ir kliento šuns ịtraukimas ị pagalbos procesą (tiek vertinant kliento situacija, tiek kaip potencialus psichologinės paramos šaltinis).

Dirbti su šunimis gali įvairų pasirengimą turintys asmenys (socialiniai darbuotojai, kitų pagalbos profesijų atstovai ir savanoriai), bet nuo šuns ir specialisto pasirengimo priklauso intervencijos gilumas ir tikslingumas. Pasinaudoti kontakto su šunimi teikiama nauda gali praktiškai visų amžiaus grupių žmonės, tai vienas plačiausiai pritaikomų žmogaus gyvenimo kokybès gerinimo būdų, turintis santykinai nedaug taikymo apribojimų. Tačiau kol kas Lietuvos kaniterapijos entuziastai koncentruojasi $\underset{i}{\text { tas }}$ grupes, kurios labiausiai matomos - institucionalizuotus neigaliuosius ir/ar vaikus.

Užsienio tyrimai ir praktika pateikia vis daugiau įrodymų apie šuns ir žmogaus ryšio nauda, netgi kuriasi pirmosios studijų programos, specialiai skirtos žmogaus ir gyvūnų ryšio panaudojimo socialiniam darbui galimybėms. Mūsų ịsitikinimu, Lietuvoje taip pat reikalingas akademinès bendruomenès îsitraukimas ne tik praturtinant būsimų pagalbos specialistų studijas, bet ir plètojant šios srities tyrimus.

\section{LITERATŪRA}

1. Arkow, P. (2007). Animal maltreatment in the ecology of abused children: Compelling research and responses for prevention, assessment, and intervention. Protecting Children, 22 (3/4): 66-79.

2. Ascione, F. R. (2005). Children and animals: Exploring the roots of kindness and cruelty. Purdue University Press.

3. AVMA (American Veterinary Medical Association) http://www.avma.org

4. Chandler, C. K. (2005). Animal assisted therapy in counseling. CRC Press.

5. Chu, C. I., Liu, C. Y., Sun, C. T., Lin, J. (2009). The effect of animal-assisted activity on inpatients with schizophrenia. Psychosoc Nurs Ment Health Serv, 47 (12): 42-48.

6. Coakley, A. B., Mahoney, E. K. (2009). Creating a therapeutic and healing environment with a pet therapy program. Complementary therapies in clinical practice, 15 (3): 141-146.

7. Corbin, J., Strauss, A. (Eds.). (2008). Basics of qualitative research: Techniques and procedures for developing grounded theory. Sage.

8. Corsini, R. J., Wedding D. (2011). Šiuolaikinè psichoterapija. Kaunas: Informatika ir poligrafija. 
9. De Viney, E., Dickert, J., Lockwood, R. (1998). The care of pets within child abusing families. Cruelty to Animals and Interpersonal Violence. Ed. Randal Lockwood and Frank R. Ascione. West Lafayette: Purdue: 305-313.

10. Fick, K. M. (1993). The influence of an animal on social interactions of nursing home residents in a group setting. The American Journal of Occupational Therapy, 47 (6): 529-534.

11. Fine, A. H. (2010). Incorporating animal-assisted therapy into psychotherapy: guidelines and suggestions for therapists. Handbook on animal-assisted therapy: Theoretical foundations and guidelines for practice. Academic Press: 169-193.

12. Kaniterapijos pradžiamokslis. Prieiga per internetą: http://www.kinologija. $1 \mathrm{t} / ? \mathrm{p}=17453$. Žiūrèta 2014-01-23.

13. Kreivinienè, B., Perttula, J. (2012). Dolphin assisted therapy in Lithuania: expectations of families raising children with complex disability. Special Education, (2): 153-163.

14. Kreivinienè, B., Rugevičius, M. (2009). Delfinu terapija Lietuvos jūru muziejuje. Klaipėda: Klaipédos universiteto leidykla.

15. Kruger, K. A., Trachtenberg, S. W., Serpell, J. A. (2004). Can animals help humans heal? Animal-assisted interventions in adolescent mental health. Center for the Interaction of Animals and Society, University of Pennsylvania School of Veterinary Medicine: 1-38.

16. Kruger, K., Serpell, J., (2010). Animal-assisted interventions in mental health: Definitions and theoretical foundations. Handbook on animal assisted therapy: Theoretical foundations and guidelines for practice. London: Academic Press: 33-48.

17. Marcus, D. A., Bernstein, C. D., Constantin, J. M., Kunkel, F. A., Breuer, P., Hanlon, R. B. (2012). Animal-Assisted Therapy at an Outpatient Pain Management Clinic. Pain Medicine, 13 (1): 45-57.

18. Martin, F., Farnum, J. (2002). Animal-assisted therapy for children with pervasive developmental disorders. Western Journal of Nursing Research, 24 (6): 657-670.

19. Melson, G. F., Melson, L. G. (2009). Why the wild things are: Animals in the lives of children. Harvard University Press.

20. Merz-Perez, L., Heide, K. M. (2004). Animal cruelty: Pathway to violence against people. CA: Rowman Altamira.

21. Risley-Curtiss, C., Holley, L. C., Wolf, S. (2006). The animal-human bond and ethnic diversity. Social Work, 51 (3): 257-268.

22. Rogers, C. R. (2005). Apie tapimą asmeniu. Psichoterapeuto požiūris i psichoterapija. Vilnius: VIA RECTA.

23. Rutkienė, J., Straubergaite, L., Baranauskienė, J., Savenkovienė, A. (2012). Jojimo terapijos poveikis autizmu sergančio vaiko psichomotorinès raidos kaitai. Jaunuju mokslininku darbai, 1 (34): 210-216.

24. Šapurova, V., Lesinskienė, S., Grikinienè, J. (2013). Hipoterapijos taikymo galimybės kompleksiniame vaikų sveikatos gerinime. Neurologijos seminarai, 17 (2): $128-131$. 
25. Šinkariova, L., Gudonis, V., Trakūnaitè, V. (2008a). Naminių gyvūnèlių laikymo sąsajos su įvairiais žmogaus gyvenimo aspektais. Jaunuju mokslininku darbai, 2 (18): 198-206.

26. Šinkariova, L., Trakūnaitė, V., Gudonis, V. (2008b) Nuo bendravimo su naminiais gyvūnèliais iki terapijos: teorinis aspektas. Jaunuju mokslininku darbai, (20): 239-244.

27. Sobo, E. J., Eng, B., Kassity-Krich, N. (2006). Canine visitation (pet) therapy pilot data on decreases in child pain perception. Journal of Holistic Nursing, 24 (1): 51-57.

28. Soproni, K., Miklósi, Á. (2001). Comprehension of Human Communicative Signs in Pet Dogs (Canis familiaris). Journal of Comparative Psychology, 115 (2): 122-126.

29. Straubergaitė, L., Jocas, D. (2008). Kineziterapeutų ir kitų specialistų bendradarbiavimo problemos. Jaunuju mokslininku darbai, 2 (18): 191-197.

30. Straubergaitè, L., Berneckè, V., Muckus, K., Juodžbalienė, V. (2011). Jojimo poveikis vaiku tiesiamojo nugaros raumens pasyviosioms mechaninèms savybèms. Specialusis ugdymas, 2 (25): 143-156.

31. Tedeschi, P., Fitchett, J., Molidor, C. E. (2006). The incorporation of animalassisted interventions in social work education. Journal of Family Social Work, 9 (4): 59-77.

32. Tsai, C. C., Friedmann, E., Thomas, S. A. (2010). The effect of animal-assisted therapy on stress responses in hospitalized children. Anthrozoos: A Multidisciplinary Journal of The Interactions of People \& Animals, 23 (3): 245-258.

33. Večkienè, N., Anužienè, I. (2011). Hipoterapijos kaip alternatyvaus socialinio darbo metodo veiksmingumas vaikams su fizine negalia socialinès izoliacijos ìveikimo procese: tèvu požiūris. Socialinis darbas. Patirtis ir metodai, 7 (1): 175-192.

34. Virányi, Z., Gácsi, M., Kubinyi, E., Topál, J., Belényi, B., Ujfalussy, D., Miklósi, Á. (2008). Comprehension of human pointing gestures in young human-reared wolves (Canis lupus) and dogs (Canis familiaris). Animal Cognition, 11 (3): 373-387.

35. Walsh, P. G., Mertin, P. G., Verlander, D. F., Pollard, C. F. (1995). The effects of a 'pets as therapy'dog on persons with dementia in a psychiatric ward. Australian Occupational Therapy Journal, 42 (4): 161-166.

36. Walton-Moss, B. J., Manganello, M. P. H. (2005). Risk factors for intimate partner violence and associated injury among urban women. Journal of community health, 30 (5): 377-389.

37. Yeh, M. L. (2013, July). The Effectiveness of Using Therapeutic Dog Program on The Elderly with Dementia in Nursing Homes of Taiwan. Sigma Theta Tau International's 24th International Nursing Research Congress. STTI. 
SUMMARY

\section{THE USE OF CONTACT WITH A DOG IN THE PROCESS OF SOCIAL SUPPORT}

There is currently no research on the use of contact with a dog in the process of social support in Lithuania. So, the aim of this research is to reveal the wide variety of possibilities to apply human-dog bond in professional social work interventions. To reach this goal analysis of scientific literature and qualitative research was made. There were 6 informants interviewed: two experts from United States, two pioneers of dog assisted interventions in Lithuania, and two social workers, who are interested in dog assisted activities and apply them in their voluntary or work practice. Data analysis has been conducted using principles of grounded theory method.

Results of research have shown that dogs are highly reliable and predictable therapy animals that almost every group of clients can benefit from. From the perspective of Humanistic theory we can state that integration dogs in the process of social support helps to create preconditions for relationship with client (enhance congruence, unconditional positive regard and empathy). The use of contact with a dog as a social support professional might be twofold: (1) interventions with assistance of therapy dog (presence of dogs, petting, playing, training, congruence, etc.) and use of family dogs (for evaluation of family dynamics or for psychosocial support). Appropriate training is needed to achieve the best results in practice of dog assisted social work.

There are only initial private initiatives appearing in Lithuania that aim to provide social support using human - dog bond. Thus we recommend that academic community work together with practitioners towards development of dog assisted interventions in Lithuania, enriching social work students' curriculum, and academic acknowledgment of this method. 